\title{
Brazilian Pine (Araucaria angustifolia (Bertol.) Kuntze) Ethnoecology in the Mantiqueira Atlantic Forest
}

\author{
Mariana Martins da Costa Quinteiro ${ }^{1}$ (D), Brenda da Rocha Alexandre ${ }^{2}$ (D), \\ Luis Mauro Sampaio Magalhães ${ }^{3}$
}

\footnotetext{
${ }^{1}$ Departamento de Ciências Ambientais, Universidade Federal Rural do Rio de Janeiro - UFRRJ, Seropédica/RJ, Brasil

${ }^{2}$ Departamento de Ecologia, Universidade Federal do Rio de Janeiro - UFRJ, Janeiro/RJ, Brasil

${ }^{3}$ Departamento de Ciências Ambientais, Universidade Federal Rural do Rio de Janeiro - UFRRJ, Seropédica/RJ, Brasil
}

\begin{abstract}
Araucaria angustifolia is under the domain of the Atlantic Forest, classified as Mixed Ombrophilous Forest (FOM). It is a native species critically threatened due to the intense exploration, to the point of exhaustion, of its natural reserves. This study aims to present the ethnoecological knowledge regarding this species in a community located in the Mantiqueira Atlantic Forest, southeastern Brazil, contrasting the results with information gathered in the literature. Brazilian Pine is a symbol of the local Pine Forest, and it is the most represented species in use categories. The ethnoecological survey included structured interviews with 20 key informers and 10 local artisans. Results indicated that the species is under strong pressure due to its exploration and use in the region; however, they also indicated that popular wisdom should be valued and applied as an effective tool for the conservation of this species. Sustainable management of the Araucaria Forests as a resource should be valued as an alternative to this objective.
\end{abstract}

Keywords: Mixed Ombrophilous Forest, Paraná pine; Visconde de Mauá; ethnobotany. 


\section{INTRODUCTION AND OBJECTIVES}

The genus Araucaria appeared nearly 200 million years ago, and comprises 19 species that occur in the southern hemisphere exclusively (Joly, 1975). In the American Continent, there are only two species: Araucaria araucana (Molina) K. Koch, in Chile and Argentina, and Araucaria angustifolia (Bertol.) Kuntze, in Brazil (Joly, 1975). Araucaria angustifolia is also known as Parana pine tree, Brazilian pine tree, or Candelabra tree and is under the domain of the Atlantic Forest, classified as Mixed Ombrophilous Forest (FOM). It is also referred to as "Pine forest", "Pinewoods" or "Araucaria Forest", and its areas of natural occurrence are regions with ecological tension between Semidecidual Forest and Dense Rainforest, as well as refuges in the Sea Mountain range (Serra do Mar) and Mantiqueira Hills (Serra da Mantiqueira) (IBGE, 1996). Araucaria angustifolia occurs in regions where the average temperature varies between 12 and $18{ }^{\circ} \mathrm{C}$, resisting frosts of $-10^{\circ} \mathrm{C}$, and is typified as a temperate climate species (IBGE, 1996).

However, data from IBGE (1996) indicate that over the geological periods, A. angustifolia presented a geographic dispersion very different from the current presentation; fossils have been found even in the Brazilian Northeast region. Currently, it has a wide range of distribution, thus contributing for its differentiation in local varieties or ecotypes (IBGE, 1996).

In terms of human use, the Parana Pine is an intensively explored native species, almost to the point of exhaustion of its natural reserves. The intense process of predatory use of these trees, especially from the beginning of the $19^{\text {th }}$ century, reduced the species natural reserves to less than $3 \%$ of its original area (Machado \& Siqueira, 1980). There are data in the literature estimating the existence of $12.6 \%$ of the original coverage of the FOM in 2009 (Ribeiro et al., 2009). Four years later, it was classified by the International Union for Conservation of Nature (IUCN) as critically threatened (Thomas, 2013). It also appears on the Official List of Species of Brazilian Flora Threatened by Extinction (Brasil, 2008).

These data are in agreement with the fact that the species has a broad variety of uses, with indication for the production of cellulose and manufacturing of paper, plywood, laminate, furniture, frames, sounding board, pianos, sticks for brooms and tools, matches, toothpicks, and sports equipment (EMBRAPA, 2002). It is also indicated for rural constructions (Angeli \& Stape, 2003; Quinteiro et al., 2015). The Pine nut is rich in energetic reserves, and is useful for feeding humans, domestic animals such as swine, and the wild fauna (Quinteiro et al., 2015). When the nut is processed, the flour obtained is used for making pies, bread, and cakes, among other recipes (Angeli \& Stape, 2003; Quinteiro et al., 2015). It is also possible to extract resin from this species, mainly from the bark. Tar, oils, turpentine, pitch, varnish, acetone, and pyroligneous acid are obtained from the distilled resin and present several industrial applications, being used to compose other chemical products (EMBRAPA, 2002). The Parana Pine bark, due to its high concentration of resin, also presents a considerable calorific value, and is indicated for energy generation (Aquino, 2005). Medicinally, the nut is prescribed against heartburn, anemia, and weakness (EMBRAPA, 2002). The leaves, when cooked, are used against tumors caused by lymphatic disorders (Angeli \& Stape, 2003).

In the region of the municipality of Visconde de Mauá, in the Mantiqueira Hills, Pine is a symbol of the local FOM, and is the species with the largest number of use categories in the region (Quinteiro et al., 2015). Therefore, the species versatility and intensity of use in the region, combined with its biological and ecological characteristics and the type of local land use and occupation - deforestation, loss of riparian vegetation, pollution, silting of rivers, decreased vegetal cover, etc. - may jeopardize its conservation (Quinteiro et al., 2015).

One of the strategies to achieve the conservation objective is to consider the traditional culture of social groups with strong connections to nature and involve the local community in these proposals. In many cases, the objectives of biodiversity conservation are not fulfilled when local communities are excluded from the process (Quinteiro et al., 2015). In this sense, the conservation of this species can be greatly enhanced if use and management alternatives are proposed and implemented (Mazza et al. 2012; Rosot, 2007).

As observed, one of the major problems associated with the conservation of FOM is the restriction of the use of this phytogeography unit. Even remnants existing on private property cannot be managed 
sustainably (restriction through law prohibition) because they add direct income to owners, reducing potential areas of use. This results in the conversion of the native vegetation areas to cultivation and pasture areas, with consequent inhibition of regeneration of the Araucaria Forest.

In this context, this study aims to present an inventory on the Araucaria angustifolia ethnoecological knowledge in a community located inside a FOM in southeastern Brazil and compare the results with information gathered in the literature. Furthermore, it seeks to examine and contribute to the management of this species in the context of local Conservations Units.

\section{MATERIAL AND METHODS}

\subsection{Study area}

This study was conducted in the municipality of Visconde de Mauá, a part of the Environmental Protection Area (APA) of the Mantiqueira Hills, a region with intense tourism surrounding the Itatiaia National Park (RJ/MG) and Pedra Selada State Park (RJ) (Figure 1). The location, settled in the Atlantic Forest domain, encompasses three municipalities: Resende (RJ), Itatiaia (RJ), and Bocaina de Minas (MG), and comprises the High Rio Preto Microbasin. Vegetation in Visconde de Mauá is classified as a transition between mixed ombrophilous forest (FOM) and high-mountain rainforest (Oliveira-Filho et al., 2004).
Climate in the region is tropical mesothermal (Köppen Cwa), with a dry winter, hot and rainy summer, and high rainfall index; the average temperature and rainfall varies from 18 to $21^{\circ} \mathrm{C}\left(64^{\circ} \mathrm{F}-70{ }^{\circ} \mathrm{F}\right)$ and 1500 to $1800 \mathrm{~mm}$, respectively, throughout the year (INMET, 2007). Average altitude is $1200 \mathrm{masl}$, and many headwaters of the Rio Preto river are located in this region.

\subsection{Data collection}

The fieldwork included monthly trips, five-day long on average, from November 2007 to May 2009. The ethnoecological survey was performed according to ethnobotanical procedures described by Albuquerque et al. (2008). It includes structured and informal interviews with 20 key informants from the community and 10 artisans from local street markets; selection of informants according to the snowball sample; guided tour for the verification in situ of the species; participant observation recorded in field diary and authorized recording of data.

\section{RESULTS AND DISCUSSIONS}

\subsection{Profile of the informants}

Two different groups of informants were identified in the community of Visconde de Mauá, with distinct uses of A. angustifolia. The first group was composed of 20 local specialists who stood out for using Parana Pine

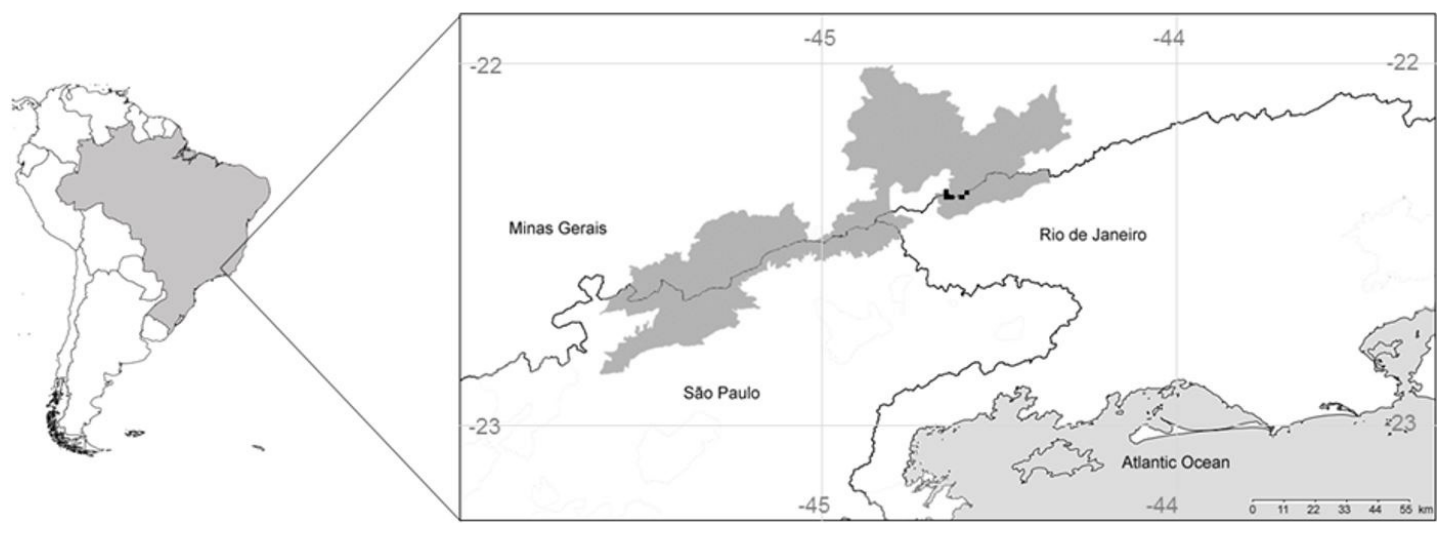

Figure 1. Study site and location of the Serra da Mantiqueira Environmental Protection Area (gray), Rio de Janeiro state, Brazil. Small squares denote the location of the villages of the Visconde de Mauá municipality: Mauá, Maromba, Maringá, Santa Clara, Lote 10, and Ponte dos Cachorros. Adapted from IBAMA (2007). 
in different categories as medicine, food, construction material, and fuel, as well as symbolic uses. They are the holders of traditional recipes of flour, bread, cakes, and potions, and also follow the traditional style to manufacture furniture and parts of houses. This group was classified according to use category of vegetation resources, identified as medicine collectors, users, faith healers, medicine men, artisans, and small farmers. Most informers belonged to more than one of the use categories aforementioned, thus avoiding their classification under one group exclusively.

The second group was composed of 10 local artisans who are not traditionally from Visconde de Mauá, but moved there to make a living from art crafts. They handle the species directly for making artisanal products - costume jewelry, ornaments, beer, brandy, jar food, handmade papers, musical instruments, toys, etc. - later sold in street markets or small shops to generate income.

The same interviews were performed for both groups. Among the local specialists, 12 were males and eight females. Six were aged 35-45 years, three 45-55 years, five 55-65 years, and six over 65 years. Regarding formal education, half of them had never been to school or had incomplete primary education, six had not finished elementary school, three had not finished high school, and only one had a college degree.

Among the artisans, six were males and four females, none of which were born in Visconde de Mauá, coming from different parts of Brazil. Six were aged 35-45 years, three $45-55$ years, and one 55-65 years. Regarding formal education, three had incomplete primary education, three had not finished elementary school, four had not finished high school, and no one had a college degree.

\subsection{Ethnoecological knowledge}

Parana Pine was mentioned in the following categories of vegetation use found in the literature: food for humans, wildlife, and domestic animals; medicine; building material; fuel; ornament; symbolic uses; artisanal products (Angeli \& Stape, 2003; Aquino, 2005; EMBRAPA, 2002; Quinteiro et al., 2015). The popular data gathered in the region of Visconde de Mauá, when compared to literature information, is consistent in the following aspects: a) First strobili

Among the respondents, four reported that it takes from 10 to 20 years for Araucaria to develop the "pinecone ball". In the literature, the Parana Pine first strobili usually occur before 15 years of age in plants cultivated separately and before 20 years of age in natural population (Aquino, 2005).

b) Time for developing the pine nut

Three respondents said it takes more than two years for the pinecone to appear, after pollination. According to Mantovani et al. (2004), the reproductive cycle of Parana Pine, from pollination to development of the seeds is long. It occurs in 20 to 24 months, from emergence of the strobili to fall of the seeds (Mantovani et al., 2004).

c) Pine nut sowing

Seven respondents affirmed that it is better to plant the pine nut right after harvesting, putting it in a humid place to sprout; or to dry it under the sun so it is not infested with borers, if one wants to keep it for a year. Bianchett \& Ramos (1981) comment that the Araucaria angustifolia seeds quickly loose their viability, recommending sowing the seeds immediately after harvest. According to the authors, this fact results from the presence of insect larvae that destroy the embryo or the moisture content during harvesting. They reported that drying the seeds at $45{ }^{\circ} \mathrm{C}$ significantly reduces their humidity content and viability.

d) Pine nut time of occurrence

According to twenty respondents, seeds from Araucaria angustifolia can be found between February and June. Another ten reported their occurrence as of April, and two informed it occurs until July. However, two local specialists stated that the time of occurrence of the pine nut have been "procrastinating" or "anticipating" according to the rainfall regime, and three commented that their occurrence has been "anticipating" over the years. Aquino (2005) reports that pine nuts are found in larger amounts between April and June. Mantovani et al. (2004) observed that the maturation and fall of pine seeds occur from March to June

e) Interaction with fauna

All the respondents reported consumption of pine nut by the wild fauna and domestic animals. Twelve mentioned lowland paca, bush mice, and horses; ten mentioned wild pigs; eight mentioned cows and squirrels, 
six mentioned pionus; four mentioned azure jay and common agouti, and two mentioned snake, coati, cavy, mini-macaw, monkey, red-rumped cacique, pyrrhura, chipmunk, domestic pig, dog, guan, little birds, and rabbit. According to Zechini et al. (2012), pine nuts serve as food for many wild animals, mainly rodents and birds, which also act as dispersers of this species.

f) Parana Pine varieties or ecotypes

Seven respondents differentiated "types" (varieties) of Parana Pine: The "Batuque" and "Farinha", and one identified a third type, with no specific name. The type "Farinha" is more appreciated because is larger and "softer to eat". Regarding the places of occurrence of the different varieties, three respondents reported that not all of them are found in the same places, that is, different varieties occur in different landscape units. The "Farinha" pine nut, for example, was recognized to occur in a place called "high marshes" ("alto dos brejos").

Reitz \& Klein (1966) were the first researchers to suggest possible varieties within the species, and characterized nine local varieties or ecotypes. These are based mainly upon the color and phenological characteristics of the pine nuts, classified into varieties as Araucaria angustifolia: elegans, sanctijosephi, angustifolia, caiova, indehiscens, nigra, striata, semi-alba and alba. Later, Coutinho \& Dillenburg (2010) studied the growing of plantlets in three of these varieties.

Two aspects not found in the literature include:

- Possible toxicity in the ingestion of the pine nut embryo, especially to children, causing skin sores ("pine nut sore"), as commented by seven respondents.

- Phenotypical distinction between male and female Parana Pines, mentioned by three respondents. The female is known to have the branches more concentrated on the top, once the pine cones are heavy, causing the branches to fall, whereas the males have branches from the bottom.

\subsection{Perspectives on conservation of the Araucaria Forest}

Quinteiro et al. (2015) highlighted that the set of goals and laws regulating the creation and existence of protected areas in Visconde de Mauá follows the model of most management plans of Conservation Units in Brazil. In this model, human activities are not subject to alternative or sustainable suggestions, compatible with the existence of such areas, which compromises the biodiversity conservation objectives of these areas.

In this study, the speech of many informants was in agreement with this observation. Many interviewees reported that the community sometimes acts as an "enemy" of the tree, because even in a situation where there is risk, they cannot remove it. They also said that it takes a long time for an authorization to cut the tree to be issued, and that it is not advantageous to let the seedlings grow in their backyards, not to lose the rights to use their land.

Specific citations of actions that may threaten the conservation of this species include: (1) "intentional burnings"; (2) "Araucaria bindings with wires to be more prone to be struck by lightning"; (3) "growth impediments and cutting of Araucaria seedlings in backyards", by residents who feel they might "lose their land" or "have some kind of problem with environmental laws". Therefore, four of them considered that the environmental legislation for Parana Pine "was not a good conservation strategy, once in this way nobody plants it or lets it grow". They suggested that there should be regulations and discussion about alternatives for the management of this species.

In contrast, punishments, regulations, and proposals were not associated with collection of Araucaria strobili and seeds, contrasting with the cutting of the tree for using its wood. Although they are non-timber forest products and have their extraction and commercialization regulated by law, Pine strobili are marketed freely for food and manufactures. Four respondents said that their families commercialize large amounts of strobilus and seed during harvest for improving family income. Therefore, indiscriminative seed collection, together with the popular practices of restricting the presence of adult trees may hinder Araucaria population dynamics.

Aquino (2005) highlighted that the legislation concerning the use of this species is more restrictive and punitive, aiming exclusively at species preservation, but it does not mention any intention to legally promote initiatives towards its seeding with commercial purposes. Thus, the author considers that the legislation should be improved in order to stimulate economic plantation of native trees, an effective alternative to decrease the pressure on the remaining trees. On a similar path, Rosot (2007) discussed that the great rigor of legislation was not effective in curbing deforestation or land use 
conversion practices to agriculture and livestock. The author warns about the need to conduct research on the management of Araucaria Forests, capable of supporting the preparation of legal instruments to regulate the use of forest resources and guiding policies to encourage this activity.

Recovery and conservation of the Araucaria Forests would thus be in accordance with 1) valuing of the forest as a sustainable resource; 2) development of alternative markets for goods and services resulting from the sustainable management of natural forests; 3 ) promotion and generation of knowledge and technologies for its management (Rosot, 2007). All these actions imply political will; redirecting public policies related to the forestry sector; technical training related to specific management of this forest typology; long-term research focused on monitoring and evaluation of the effects of management; recognition by society that only inspection measures and the creation of protected areas are not sufficient to contain the degradation of forest environments (Rosot, 2007). In this context, Araucaria presents good potential to increase the income of local communities, reinforcing the importance of forest remnants, and providing subsidies for the establishment of public policies that can make forest resources effective to community development and conservation by means of their use (Vieira da Silva \& Reis 2009; Ferreira et al, 2012; Figueiredo et al, 2011; Ribeiro da Silva \& Barbosa, 2012).

\section{CONCLUSION}

Araucaria angustifolia species is under severe pressure of exploration and use in the studied local community. In this sense, we differentiate the traditional use of Parana Pine, as food resource, construction material, fuel, symbolic, and medicinal, from its modern use, in gastronomic celebrations and for ornamentation in local artisanal crafts.

Ethnoecological information was in agreement with different data from the literature on Araucaria, indicating that local popular knowledge should be valued and used as a useful tool for effective environmental planning. This local knowledge proved to be important also in the community's perception of the landscape, the importance and abundance of resources, and of how these resources are managed on their natural habitat.

The environmental legislation in force in protected areas has proved to be insufficient, and often incoherent, for the purpose of conserving this species. Therefore, improvement in merely punitive measures is necessary, expanding educational initiatives, and promoting activities involving the sustainable management of this species.

In this sense, proposals of forest management have been indicated as an effective way to counter fragmentation of the Araucaria Forest, especially the ones that contemplate the communities inserted in its region of natural occurrence. Conservation of the Araucaria Forest seems to be directly associated with the final representation and perception that this domain has for these communities.

\section{ACKNOWLEDGEMENTS}

The authors are grateful to all the informants in the community of Visconde de Mauá, who gently agreed to participate in this research; to Mark Hickie, for language revision; to Instituto Brasileiro do Meio Ambiente (IBAMA), for authorizing this study; and to CAPES and PROEX/UFF, for the scholarships provided.

\section{SUBMISSION STATUS}

Received: 3 may, 2016

Accepted: 30 jun., 2018

\section{CORRESPONDENCE TO}

\section{Mariana Martins da Costa Quinteiro}

Rodovia BR 465, Km 7, Campus Universitário,

Zona Rural, CEP 23851-970, Seropédica, RJ,

Brasil

e-mail: marianaquinteiro@gmail.com

FINANCIAL SUPPORT

CAPES, Phd scholarship

PROEX/UFF, Extension scholarship

\section{REFERENCES}

Albuquerque UP, Lucena RFP, Neto EMFL. 2008. Seleção e escolha dos participantes da pesquisa. In: Albuquerque UP, Lucena RFP, Cunha LVFC, organizadores. Métodos e técnicas na pesquisa etnobotânica. 2. ed. Recife: NUPPEA; 2008. p. 21-40 
Angeli A, Stape JL. Araucaria angustifolia (Araucária) [online]. Piracicaba: IPEF; 2003 [cited 2009 June 06]. Available from: http://www.ipef.br/identificacao/araucaria. angustifolia.asp

Aquino FM. Cultivo de Araucaria angustifolia: análise de viabilidade econômico financeira. Florianópolis: BRDE; $2005.53 \mathrm{p}$.

Bianchett A, Ramos A. Efeito da temperatura de secagem sobre o poder germinativo de sementes de Araucaria angustifolia (Bert.) O. Ktze. Boletim de Pesquisa Florestal 1981; 2: 27-39.

Brasil. Ministério do Meio Ambiente. Instrução Normativa $n^{\circ}$ 6, de 26 de setembro de 2008. Lista Oficial das Espécies da Flora Brasileira Ameaçadas de Extinção. Diário Oficial da República Federativa do Brasil, Brasília, DF (2008 set.). [cited 2018 June 5]. Available from: http://www.mma.gov. br/estruturas/179/_arquivos/179_05122008033615.pdf.

Coutinho AL, Dillenburg LR. Comparision of seedling growth among three co-ocurring varieties of Araucária under greenhouse conditions. Acta Botanica Brasílica 2010; 24: 567-570.

Empresa Brasileira de Pesquisa Agropecuária - EMBRAPA. Cultivo do Pinheiro-do-Paraná. Brasília: Embrapa; 2002. [cited 2007 June 22]. Available from: http://sistemasdeproducao. cnptia.embrapa.br/FontesHTML/Pinheiro-do-Parana/ CultivodoPinheirodoParana/sistema/08_solos.htm.

Ferreira DK, Nazareno AG, Mantovani A, Bittencourt R, Sebbenn AM, Reis MS. Genetic analysis of 50-year old Brazilian pine (Araucaria angustifolia) plantations: implications for conservation planning. Conservation Genetics 2012; 13: 435-442.

Figueiredo A Fo, Orellana E, Nascimento F, Dias AN, Inoue MT. Produção de sementes de Araucaria angustifolia em plantio e em floresta natural no Centro-sul do Estado do Paraná. Floresta 2011; 41(1): 155-162.

Instituto Brasileiro de Geografia e Estatística - IBGE. Anuário Estatístico do Brasil. Rio de Janeiro: IBGE; 1996 [cited 2007 Sept 8]. Available from: https://biblioteca. ibge.gov.br/visualizacao/periodicos/20/aeb_1996.pdf

Instituto Brasileiro do Meio Ambiente e dos Recursos Naturais Renováveis - IBAMA. Brasília: IBAMA; 2007 [cited 2007 Sept 8]. Available from: www.ibama.gov.br

Instituto Nacional de Meteorologia - INMET. Normais climatológicas [online]. Brasíli; 2007. [cited 2007 Aug 13] Available from: www.inmet.gov.br

Joly AB. Botânica: introdução à taxonomia vegetal. 2. ed. São Paulo: Editora Nacional/EDUSP; 1975.777 p.

Machado SA, Siqueira JDP. Distribuição natural da Araucaria angustifólia (Bert.) O. Ktze. In: Forestry problems of the genus Araucaria; 1979; Curitiba. Curitiba: FUPEF; 1980. p. 4-9.

Mantovani A, Morellato LPC, Reis M. Fenologia reprodutiva e produção de sementes em Araucaria angustifolia (Bert.) O. Kuntze. Revista Brasileira de Botanica. Brazilian Journal of Botany 2004; 27: 787-796.

Mazza CAS, Mazza MCM, Steenbock W, Marques W, Marques AC, Weirich RO et al. Conservação e uso dos recursos florestais não madeiráveis da floresta com araucária: Programa Conservabio. Colombo: Embrapa Florestas; 2012.

Oliveira-Filho AT, Carvalho DA, Fontes MAL, van den Berg E, Curi N, Carvalho WAC. Variações estruturais do compartimento arbóreo de uma floresta semidecídua alto-montana na chapada das Perdizes, Carrancas, MG. Revista Brasileira de Botanica. Brazilian Journal of Botany 2004; 27: 291-309.

Quinteiro MMC, Tamashiro AMG, Guerra MS, Pinto LJS, Moraes MG. Inventory and implications of plant use for environmental conservation in Visconde de Mauá, Serra da Mantiqueira, Brazil. Ethnobotany Research and Applications 2015; 14: 27-47.

Reitz R, Klein RM. Araucariaceae. Itajaí: Herbário Barbosa Rodrigues; 1966. 62 p.

Ribeiro MC, Metzger JP, Martensen AC, Ponzoni F, Hirota M. Brazilian Atlantic forest: how much is left and how is the remaining forest distributed? Implications for conservation. Biological Conservation 2009; 142: 1141-1153.

Ribeiro da Silva, C. J.; Barbosa, H. A. Registros de entrada e coleta de pinhões na Floresta Nacional de três barras. In: MINISTERIO DO MEIO AMBIENTE/MMA. Livro de Registros da Floresta Nacional de Três Barras. Brasilia: ICMBio. 2012

Rosot MAD. Manejo florestal de uso múltiplo: uma alternativa contra a extinção da floresta com Araucária. Pesquisa Florestal Brasileira 2007; 55: 75-85.

Thomas P. Araucaria angustifolia [online]. Cambridge: The IUCN Red List of Threatened Species; 2013 [cited 2001 Apr 6]. Available from: www.iucnredlist.org.

Vieira da Silva C, Reis MS. Produção de pinhão na região de Caçador, SC: aspectos da obtenção e sua importância para comunidades locais. Ciência Florestal 2009; 19(4): 363-374.

Zechini AA, Schussler G, Silva JZ, Mattos AG, Peroni N, Mantovani A et al. Produção, Comercialização e Identificação de Variedades de Pinhão no Entorno da Floresta Nacional de Três Barras - SC. Biodiversidade Brasileira 2012; 2(2): 74-82. 